\title{
ESSENTIALISM IN ENVIRONMENTAL PSYCHOLOGY: CONTROVERSIES AND EVIDENCE*
}

\author{
Maria Lewicka \\ Institute of Psychology, Nicolaus Copernicus University in Toruń
}

\begin{abstract}
This paper deals with the issue of psychological essentialism as present in environmental studies. The essentialist belief - that is, the assumption that things have a deep essence that defines their stable identity - has been a recurring theme in environmental psychology. In this paper, I show its relevance for such research areas as environmental perception and the concept of place as a meaningful location. I show that essentialism underlies early phenomenological theories of place and is present in contemporary biophilic theories of environmental perception. I discuss relevant theories and present research findings that justify the claim that people are psychological essentialists when dealing with the physical built environment.
\end{abstract}

Keywords: essentialism; place; built environment; environmental perception.

Psychological essentialism is the belief that things have an inner essence that defines their nature and gives rise to their observable features (Gelman, 2003; GilWhite, 2001; Medin \& Ortony, 1989). Its corollary posits that while observable features may be subject to change, the thing's essence is immutable. Psychological essentialism is not the same as ontological essentialism, a philosophical position

MARIA LEWICKA, https://orcid.org/0000-0002-6060-467X. Correspondence concerning this article can be addressed to Maria Lewicka, Katedra Psychologii Społecznej i Środowiskowej, Uniwersytet Mikołaja Kopernika w Toruniu, Fosa Staromiejska 1A, 87-100 Toruń, Poland; e-mail: marlew@umk.pl.

* The preparation of this paper was financed with a research grant from the National Science Centre, No. 2017/25/B/HS6/00137.

Handling editors: Magdalena Szubielska \& Pawę Stróżak, John Paul II Catholic University of Lublin.

Received 10 May 2021. Received in revised form 5 Sept. 2021. Accepted 18 Sept. 2021. Published online 13 Oct. 2021. 
habitually attributed first to Aristotle, which assumes that such is the nature of things, that is, things indeed can be defined through their deep and immutable essence. Compared to ontological essentialism, psychological essentialism refers to human convictions about the nature of things, not to the nature itself. In this paper, the focus will be on psychological essentialism, as represented by laypeople, and as confronted with theoretical approaches represented by scholars in such diverse areas as geography, architecture, environmental psychology, and environmental aesthetics.

\section{PEOPLE AS PSYCHOLOGICAL ESSENTIALISTS}

According to Medin (1989), psychological essentialism is a placeholder, which means that people assume that categories have an essence without knowing the content of this essence. It is only later, as a result of cognitive effort and elaboration, that they fill this impalpable and intuitive core with specific content; for example, they refer to DNA when explaining gender differences or to "national soul" in the case of ethnic differences. When evaluating places, people tend to speak about their genius loci-a difficult to define "spirit" of place that determines the place's unique identity.

Drawing from philosophy and critical social theory, Haslam et al. (2000) isolated several features that characterize essentialist beliefs. First, essentialist categories can be defined in terms of a finished set of sufficient and necessary features. This means that sharp boundaries exist around an essentialist category, and a category exemplar either is or is not its member. Essentialist categories do not leave room for ambiguities (e.g., neither male nor female), double membership (e.g., a Polish Jew) or hybrids. Essentialist categories therefore unequivocally determine the identity of their members: being a member of one category eliminates its membership in other same level categories. Second, the essentialist categories have a high inductive potential; in other words, once the category membership is known, it is possible to draw causal inferences about various features characterizing members of this category. Examples are stereotypes in which category membership is usually associated with an extensive network of causal inferences (Yzerbyt et al., 1997). Third, the category essence is immutable and historically invariant. Categories are "forced", that is, one cannot stop being a member of an essentialized category (a Jew will always be a Jew irrespective of his or her personal decisions; a person born a woman cannot change into a man). Fourth, categories are homogeneous: the common essence describes all members of this category, and the category members on the deepest level are all identical, despite their superficial differences. Lastly, the essentialist categories are natural: they are not man-made artifacts and people have no control over their 
content. Hence, people tend to attribute essence mostly to natural kinds, such as biological organisms and minerals, or - to a lesser extent - to these social entities that appear biologically determined (e.g., ethnic groups). Recently, however, there is also a growing interest in the essentialism of artifacts, particularly of valuable objects and objects of emotional attachments (Gelman, 2013). In the second part of this paper, I will focus on studies that address the issue of essentialism as attributed to places, which are physical settings that combine man-made and natural elements.

Within the contemporary postmodern and constructivist approach in the social sciences, essentialism is an unwelcome philosophical construct. Essentialism has been criticized for its emphasis on fixity and stability, and for sharp borders between categories, for example, between biological species, thus ignoring their intermediate and hybrid forms. This led Mayr (1968) to posit that essentialist thinking in biology has inhibited the development of the theory of evolution (see also Sober, 1980). Similar criticism has been voiced by geographers and architects. The concept of genius loci, understood as a guardian of a stable place identity, popularized by the Norwegian architect, Christian Norberg-Schulz (1980), is held responsible for inhibiting the development of new urban forms in Norway (Røe, 2014). Further, psychological essentialism has been subject to extensive studies by social psychologists who systematically demonstrated that there exists a close link between the tendency to essentialize others, particularly those belonging to an out-group, and their stereotyping, prejudice, and racism (Chen \& Ratliff, 2018; Haslam et al., 2002). This is one of the reasons why essentialism has become a "dirty word" in social sciences nowadays, and no respectful scholar would openly admit to essentialist thinking.

This discrepancy between what became a "decent norm" in the social sciences and laypeople's obvious deviation from it has not been left unnoticed. In the spirit of the times, Gil-White (2001, p. 516) wrote, "These days, 'good' anthropologists do not essentialize groups, and therefore no self-proclaimed essentialists are found in anthropology journals. But ordinary folks are not good anthropologists or sophisticated constructivist scholars. Quite to the contrary, they are naïve essentialists, and I will try to explain why." Another anthropologist wrote on the same note, "Outside the academy, however, and to the dismay of anthropologists who fancy themselves as the cultural avant-garde, essentialist identities grow ever more powerful and seductive" (Brodwin, 2002, p. 323). Such comments have led researchers, particularly cognitive psychologists, to probe deeper into the causes of psychological essentialism.

According to Gelman (2003), people's proclivity to think in essentialist terms has sources in culture, language, people's psychological makeup, and physical features of the world. For example Rhodes et al. (2012) demonstrated that use of the generic language ("X is" or "all $\mathrm{X}$ are"), compared to the non-generic language ("this X is" or "some X are"), led to formation of essentialist social categories among 
4-year-old children (see also Gelman, 2003). The authors showed that holding essentialist beliefs about a social category made children's parents use generic language more often, which in turn would induce essentialist thinking in children.

However, people also essentialize because this is their natural tendency to make sense of the world. Categorization is a cognitive operation that helps reduce a variety of stimuli. Without this ability, we would live in a totally unintelligible and unpredictable world (Medin \& Rips, 2002). People also make sense of the world by looking for the causes of observable phenomena. These causes are usually located in the features of objects (e.g., ethnic groups or other social categories), which are easier to grasp and have a higher imageability potential than the invisible and complicated network of environmental and social factors. Fundamental attribution error (Ross, 1977), also known as correspondence bias (Gilbert \& Malone, 1995), is one example of this proclivity. Cimpian and Salomon (2014) used the term "inherence heuristic" to describe the tendency to locate causes in the inherent properties of objects. Girls like pink, as the authors' example goes, because pink is a delicate and feminine color that matches the delicacy of the girls' "nature", which is the essence of "girlishness". This inherence heuristic can, of course, lead us astray, being based on false premises. Some time ago, I mentioned this example in a discussion with an Icelandic colleague who exclaimed: "Oh, but pink was the favorite color of Vikings - it was supposed to frighten off enemies."

Although the pink color turned out to be culturally constructed, essentializing often tends to be driven by observations of the physical world. Animals do indeed differ, and these differences are associated with other traits. Tigers are dangerous, while cats usually are not. Cows give drinkable milk but pigs do not. Most people are ascribed either to the male or the female sex, and the two sexes, regardless of the grounds for these differences, differ in some observable respects. Studies in genetics provide further confirmation of the biological basis of "immutable" categories. Organization of the world provides cues for essentializing. ${ }^{1}$

Gil-White (2001) posits that essentialist bias with respect to ethnic groups is a product of the evolutionarily established "living-kinds" mental module that evolved to process species-level categories. As a result, ethnic groups are perceived in analogy to the living kinds (animals, plants) in terms of category-based endogamy and

${ }^{1}$ It should be emphasized that essentialism in causal reasoning is a default option in human reasoning rather than a universal explanatory bias. As children grow up and their knowledge of the environmental causes of behaviors increases, the tendency to use essentialist explanations weakens (Gelman et al., 2007). Nevertheless, the studies also show that essentialist beliefs about some categories such as gender tend to be stable across development, while others, such as beliefs about the nature of ethnicity, are more variable across developmental stages and cultural contexts (Rhodes \& Mandalaywala, 2017). Discussion of these issues, however, goes beyond the scope of this paper. 
descent-based membership. The distinction between ingroup and outgroup, both perceived as differing in some interrelated traits, saved effort, facilitated decisions, and protected against dangers coming from a potential enemy. With a high probability, we can posit that other essentialist beliefs also have their roots in our evolution. In the next sections, I will develop this point by addressing human environmental preferences.

\section{ESSENTIALISM IN ENVIRONMENTAL PSYCHOLOGY: PLACE AS A MEANINGFUL LOCATION}

Essentialist thinking permeates early theories of place. What processes convert an emotionally sterile physical setting into a personally meaningful place? Early human geographers who initiated research on place - defined as a meaningful location (Agnew, 1987; Gieryn, 2000; Tuan, 1977) ${ }^{2}$ - were phenomenologists and their philosophical roots were in the writings of Heidegger $(1962,1970)$ and Merleau-Ponty (1945). According to Relph (1976), whose doctoral dissertation entitled Place and Placelessness was the turning point in studies of people-place relations, "The essence of place lies in the largely unselfconscious intentionality that defines places as profound centres of human existence" (Relph, 1976, pp. 42-43). The phenomenological method assumes essentialism; its purpose is to uncover the context- and culture-independent essential universals of human experience-in our case, of the sense of place (Steele, 1972). As Seamon (1980, p. 149) states, "[p]henomenology seeks the essential structure of human experience and asks if there are particular patterns which transcend specific empirical contexts and point to the essential human condition - the irreducible crux of people's life-situations which remains when all 'non-essentials' - cultural context, historical era, personal idiosyncrasies-are stripped bare through phenomenological procedure." By stripping the accidental "noise" away from experience, the phenomenological approach helps to uncover the essence of people's experience of "emplacement" and identify the main properties of this experience. Some of these properties were drawn from the writings of early phenomenologists (see Malpass, 2008), and some were added later by architects whose phenomenological experience was mostly with the built environment, that is, cities and buildings (Norberg-Schulz, 1980). Here is their short list:

${ }^{2}$ For a detailed discussion of the concept of place as present in environmental psychology and related sciences, and the discussion of how to understand the concept of the "meaningful location", see Lewicka 2012, chapter 1. 
Sense of insideness and place boundaries. Phenomenologists emphasize that place acquires its meaning through the phenomenological experience of being-inthe-place. The concept draws from Heidegger's (1962) concept of "being-in the world" and has been transformed by Relph (1976) into a continuum of insideness, from a full sense of immersion in a place (existential insideness) through its partial forms, such as empathetic, incidental, and vicarious insideness, to various forms of outsideness. Being "inside", as an essential component of the experience of place, is also indirectly present in Tuan (1977) in his well-known statement that place is rest while space is movement. Of course, being inside requires that there is also an outside, and therefore meaningful places should have boundaries around them.

Naturalness and authenticity. The concept of "authenticity" also draws from Heidegger's philosophy. Human relations with place are assumed to be an authentic natural attitude - "the unnoticed and unquestioned acceptance of the things and experiences of daily living" (Seamon, 1980, p. 149). For Heidegger, the best exemplification of this experience was rural life, contrary to the consumerist lifestyle carried out in artificial environments and man-made simulacra.

Rootedness. The essence of the people-place bond is "dwelling" (Heidegger, 1970), which is a prolonged stay in a place associated with the sense of its appropriation and rootedness. Hence, not surprisingly, the best symbol of place is home, which is understood as an object of special care and attachment (Bachelard, 1994; Porteous, 1976). Home offers stability over time and protection against the "outside". Home is a setting where one can experience existential insideness (Relph, 1976) and where most of one's daily routines are located (Seamon, 1980).

Distinctiveness, identity, and genius loci. Human geographers were soon joined by architects who also were phenomenologists. Architects design buildings; hence, this meant a shift from the nonspecific "place experience" to real examples of the (mostly built) environment. What makes a city or a building complex more meaningful than others? Being designers themselves, not just thinkers, the approach of architects was different from that of human geographers, as the focus of architects was on the features of places relative to people's experiences rather than on the experience itself. This is an important difference. Universal features of experience may be understood as manifestations of the properties of the human biological or psychological make-up, and nothing needs to be said about the nature of the "reality out there"- that is, the source of this experience. By comparison, in the writings of architects who actually create reality, there is a clear emphasis on the essential properties of specific settings (i.e., ontological essentialism). According to this view, an architect's mission is to uncover a place's essence and build the world in a way that will resonate with people's natural propensities. "The basic act of architecture is to understand the 'vocation' of the place" (Norberg-Schulz, 1980, p. 23). Places 
speak to us with their own voices; they have their own identities that make them unique. Moreover, human being's identification with a place is conditioned on the identity of the place. This identity is stable over history, and stability is guarded by genius loci, the spirit of the place. As Norberg-Schulz (1980, p. 18) put it, "[t]his spirit gives life to people and places, accompanies them from birth to death, and determines their character or essence."

Places as living organisms. Essentialist thinking is applied to natural kinds rather than to man-made artifacts. However places, particularly those built by humans, are artifacts. It is therefore understandable that thinking of places in essentialist terms has led some researchers to use biological metaphors and thus draw an analogy between the physical structures of places and natural kinds. For example, in analogy to biological organisms, researchers refer to the "organic" development of places (Alexander et al., 1975) or about the "place's DNA" (Wu \& Silva, 2011), considered a hidden resource that helps maintain the place identity despite its constant changes. More recently, Löw (2012) introduced the essentialist concept of the intrinsic logic of cities (Eigenlogik), defined as a hidden city structure, made of spatial, temporal, social, political, and affective dimensions, responsible for the city's stable and predictable pattern of development. The idea that a meaningful building or a building complex reminds a living organism is a recurring theme in architecture, and I will return to it in the last section of this paper.

The essentialist approach to place, prevalent among its early researchers, became a target of vivid criticism from scholars representing the anti-essentialist, constructivist approach (Harvey, 1993; Massey, 1993). According to this approach, meaning is not retrieved from the physical features of places but is socially constructed. The content of a social construction, in turn, is instrumental with respect to power relations and thus context specific. There is therefore nothing like an essence of place or of place experience - what is considered meaningful depends on the social context, the involved actors, and historical time. Second, in line with the mobility paradigm that dominates contemporary geography (Cresswell, 2006), the concept of rootedness as the basic relation between people and places was rejected as not matching the actual behavior of people (DiMasso et al., 2019). Rootedness, unwillingness to move may be signs of parochialism and may hinder personal development (Fried, 2000). Third, contested were the features of places assumed to make them meaningful: stability, enclosure, naturalness, and historical continuity. The majority of places are palimpsests, compounds made of different historical layers, rather than products of a continuous uniform history. The emphasis on enclosure, in turn, may lead to social segregation and xenophobia among city inhabitants (Harvey, 1993). Finally, the idea that a place has a stable identity was rejected. The contemporary, globalized world is everything but stable. Consequently, the essentialist "place as 
being" was replaced by a more valid metaphor of "place as becoming" (Dovey, 2010). All this has led to a new definition of place as open, dynamic, and fluid, as crossroads rather than specific points in space, places of lively interactions and not just rest, identities of which are created and recreated as the result of new encounters between locals and newcomers.

\section{PEOPLE AS ENVIRONMENTAL ESSENTIALISTS?}

Although the conflict between essentialist and anti-essentialist theories of place seems intractable, Lewicka et al. (2019) posited that instead of deciding whether place has an inherent meaningful essence or whether its meaning is socially constructed, it can be assumed that the two points of view address different types of places, as they refer to two sets of qualitatively different features. Both of them, however, are present in our cityscapes. The classic, "conservative" theories of early phenomenologists describe places that have clearly defined borders, have a stable and distinctive identity, have continuous history, and encourage a sense of insideness and belonging. As with all essentialist categories, conservative places are homogeneous in terms of physical and social make-up. Other places, in turn, may better conform to the "progressive" theories of social constructivists. It is not difficult to find places in our surroundings that are open and dynamic and that encourage physical and social diversity. A cozy and relaxing neighborhood vs. a bustling city square, or a small historical town vs. a lively metropolis are examples of the two types of places. Both theories - the essentialist "conservative" and the anti-essentialist "progressive" (Cresswell, 2015) - fit human environments. Which one will be considered more meaningful by lay people? The answer to this question is a task for psychologists.

In a series of studies carried out with the use of different stimuli, Lewicka et al. (Lewicka et al., 2019; Iwańczak \& Lewicka, 2020; Lewicka \& Urbańska, 2021) demonstrated that much against the claims of constructivists, people evaluate as meaningful those places that are characterized by conservative rather than progressive features. In the first study (Lewicka et al., 2019, Study 1), students representing two universities, one located in a big metropolis and another in a much smaller town, were shown a set of pictures representing various settings, both rural and urban, and asked to rate them on a scale with respect to how well they represented a meaningful place. They were also asked to write down up to five words that they associate with the content of the picture. The results showed that, without exception, the best examples of meaningful places were those that fitted the essentialist theory of place. This is best seen in the associations given to the highest ranked photos, such as: 
(1) peaceful, quiet, cozy, relaxing; (2) history, continuity, memory, nostalgia, tradition, heritage; (3) beautiful, pleasant, sentimental, romantic, home-grown, charming, joyful, happy, blissful, picturesque; (4) green, bucolic, natural, rural, harmony with nature; (5) home, homely, childhood, grandparents, family; (6) isolated, closed, far from the madding crowd, hidden, private, secluded, intimate; and (7) climatic, has soul, magical, unique, has character.

Encouraged by these findings, we ran a more systematic study (Lewicka et al., 2019, Study 2) in which we asked participants to rate a series of pictures on a scale that directly referred to essentialist and anti-essentialist features of places, for example, "This place makes people stop and rest", and "You can feel history in this place" for conservative items vs. "A lot happens in this place" and "This place changes all the time" for progressive items, and then express their liking of this place and preference for having such a setting in their vicinity. Again, the data showed that liking was significantly related to the conservative (essentialist) but not to the progressive (anti-essentialist) score and that participants would rather have conservative than progressive places in their close environment.

Finally, in the third study (Lewicka et al., 2019, Study 3), we collected ratings of 120 pictures, mostly depicting urban scenes, on a set of over 20 dimensions, descriptive of essentialist vs. anti-essentialist features, drawn from both geographical and philosophical theories of essentialism. The dimensions were designed in such a way that one of the poles always referred to a meaningful setting (a place), whereas it was opposite to a meaningless non-place (Augé, 1995). Further, the meaningful pole either described the essentialist feature, conforming to the essentialist concept of place, or to the anti-essentialist feature, fitting the anti-essentialist concept of place. The same was true of the meaningless poles. We assumed that non-places can also be described with the same sets of features; although their evaluation will be different, non-places will trigger negative affects and places positive affects. Thus, we created several sets of $2 \times 2$ matrices, one for each of the place features: essentialist place vs. anti-essentialist non-place and anti-essentialist place vs. essentialist non-place. In Table 1, we show examples of three such features and corresponding dimensions: history vs. modernity, enclosure vs. openness, and stability vs. change. Based on the way it is formulated, each pole can either describe a meaningful place or a meaningless non-place, that is, carry either a positive or a negative evaluation (Table 1). 


\section{Table 1}

Sample Dimensions Used for Evaluating Places

\begin{tabular}{|c|c|c|c|}
\hline Feature & & Essentialist (conservative) & Anti-essentialist (progressive) \\
\hline \multirow[t]{2}{*}{$\begin{array}{l}\text { Historical } \\
\text { vs. modern }\end{array}$} & $\begin{array}{l}\text { Place vs. } \\
\text { non-place }\end{array}$ & 1A. One can feel history in this place. & 1B. This is a place without history. \\
\hline & $\begin{array}{l}\text { Non-place vs. } \\
\text { place }\end{array}$ & 2A. This place is old and run-down. & 2B. This is a modern place. \\
\hline \multirow[t]{2}{*}{$\begin{array}{l}\text { Enclosed } \\
\text { vs. open }\end{array}$} & $\begin{array}{l}\text { Place vs. } \\
\text { non-place }\end{array}$ & $\begin{array}{l}\text { 3A. This is an enclosed place, it has } \\
\text { natural borders. }\end{array}$ & $\begin{array}{l}\text { 3B. This place has no borders, } \\
\text { it is difficult to say where it ends. }\end{array}$ \\
\hline & $\begin{array}{l}\text { Non-place } \\
\text { vs. place }\end{array}$ & $\begin{array}{l}\text { 4A. This place seems closed, it is } \\
\text { difficult to breathe in this place. }\end{array}$ & $\begin{array}{l}\text { 4B. This is an open place, you can feel } \\
\text { space here. }\end{array}$ \\
\hline \multirow[t]{2}{*}{$\begin{array}{l}\text { Stability } \\
\text { vs. change }\end{array}$} & $\begin{array}{l}\text { Place vs. } \\
\text { non-place }\end{array}$ & $\begin{array}{l}\text { 11A. This place has an identity that } \\
\text { does not change. }\end{array}$ & $\begin{array}{l}\text { 11B. This place changes in an uncon- } \\
\text { trollable, random and chaotic way. }\end{array}$ \\
\hline & $\begin{array}{l}\text { Non-place vs. } \\
\text { place }\end{array}$ & $\begin{array}{l}12 \mathrm{~A} . \text { This is a static place, this place } \\
\text { resists changes. }\end{array}$ & $\begin{array}{l}12 \mathrm{~B} \text {. This is a dynamic place, } \\
\text { its character changes. }\end{array}$ \\
\hline
\end{tabular}

Note. Based on Lewicka et al., 2019.

The participants also evaluated each photo on two affective dimensions (relaxing vs. irritating and exciting vs. boring) and expressed their wish to stay in this place or leave it. The four types of affect, drawn from the emotional circumplex model (Russell, 1980), were found in our studies to be markers of the type of place: relaxation of the essentialist place, excitement of the anti-essentialist place, irritation of the anti-essentialist non-place, and boredom of the essentialist non-place (Iwańczak \& Lewicka, 2020; Lewicka et al., 2019), and therefore we used these scales as further measures of the perceived meaning.

Factor analysis run on the ratings revealed two factors: one that loaded on all dimensions describing features of essentialist places vs. anti-essentialist nonplaces, and the other describing features of anti-essentialist places vs. essentialist 
non-places. ${ }^{3}$ In line with the findings of the two previous studies, the wish to stay in a place correlated significantly with the first factor (essentialist features) and did not correlate with the second factor (anti-essentialist features). Moreover, whereas (as predicted) all non-places were perceived as less attractive than places, the essentialist places were perceived as more attractive than the anti-essentialist places, and the essentialist non-places were seen as more attractive than the anti-essentialist non places. In short, the difference in attractiveness between essentialist places and anti-essentialist non-places was much greater than the difference between anti-essentialist places and essentialist non-places.

We have replicated the results in two other (unpublished) studies, using as stimuli pictures of virtual scenes drawn from computer games evaluated along the essentialist and anti-essentialist dimensions (Gembarski \& Dzieciątkowski, 2021), and in another study (Jarczyk, 2021), pictures of nature. In both studies, people's preferences were associated with the essentialist rather than anti-essentialist features of places presented in photographs.

The studies described above seem to provide evidence that humans are psychological essentialists in their environmental preferences. This conclusion, however, seems to contradict our everyday observations, which suggest that people would choose places of living that are dynamic, open, and bustling with life rather than closed and static. When asked to list their favorite cities, people usually pick up big metropolises. Further, everyday life choices testify to it: people, particularly young ones, emigrate from small and cozy towns to seek better life in bigger cities. Of course there are many reasons behind life decisions, of which only some are associated with what people consider a meaningful place. Nevertheless, this discrepancy calls for an explanation: Is it possible that our findings are caused by some uncontrollable factors?

${ }^{3}$ A hierarchical cluster analysis of data collected in Study 3 revealed a more fine-grained structure of "place essentialism", consisting of four smaller clusters, of which three corresponded to the features of places first identified by phenomenologists: (1) potential for rest, emotion of relaxation, and wish to stay longer in a place; (2) sense of insideness and genius loci, and (3) historicity, naturalness and distinctiveness; while the more distant fourth cluster consisted of social and physical homogeneity, stable identity, and physical enclosure (for details see Lewicka et al., 2019). Comparison of the structure of place essentialism with the structure of essentialism identified in other domains, mainly social groups (cf. Andreychik $\&$ Gill, 2014; Demoulin et al., 2006) suggested that dimensions of essentialism may vary depending on the domain but that there also exists an essentialist "core" that is shared by all essentialist structures and which is independent of its content. This core is best described as "entitativity" (Hamilton \& Sherman, 1996), defined by stability, presence of clear borders, and homogeneity of its elements. This is a topic that is worth pursuing in further studies. 
One possible explanation for this discrepancy lies in the use of a medium in our research. In the above-described studies, the medium was photos of places and not real physical stimuli, not even imagined places. It is therefore highly probable that the results are an artifact whose origin is an interaction between the medium used and the concept of essentialism vs. anti-essentialism. Essentialist theories of phenomenologists mostly refer to physical features of places, such as enclosure, coherence, naturalness, and historicity. In comparison, the anti-essentialist theories of constructivists refer to features of places that are socially constructed or even symbolic, such as openness, social dynamics, and change, and which are generally more difficult to identify from static pictures than the essentialist features. Even if every place were a palimpsest composed of different historical layers, a static picture would not show it. In studies by Fornara et al. (2018) run in several districts of Paris, the emotion of excitement (a marker of a "progressive" place) was mostly predicted by social aspects of the environment (e.g., the presence of cultural institutions), whereas the emotion of relaxation (a marker of a "conservative" place) was predicted by their physical aspects (up-keep, aesthetics, types of buildings). In another study (Iwańczak $\&$ Lewicka, 2020) in which photos were also used, the emotion of relaxation was mostly explained by the presence of nature on the pictures (that is a physical feature), while the emotion of excitement - by the presence of people (social aspect). Since physical aspects are easier to show on a picture than social aspects, the observed prevalence of essentialist preferences was observed in all our studies.

Would the results be different if we asked people to evaluate real places, for example, cities in which they live or which they know very well? In another study (Lewicka \& Urbańska, 2021), we asked residents of eight Polish cities, differing in the degree to which they conformed to the essentialist vs. anti-essentialist definitions, to evaluate their own city and the neighboring one on the set of essentialist vs. anti-essentialist criteria described above (Lewicka et al., 2019, Study 3). Toruń, Cracow, Gdańsk, and Przemyśl were assumed to have more essentialist features, while Bydgoszcz, Warsaw, Gdynia, and Rzeszów had more anti-essentialist features. Each essentialist city was paired with an anti-essentialist one (Toruń-Bydgoszcz, Cracow-Warsaw, Gdańsk-Gdynia, Przemyśl-Rzeszów). The findings show that, indeed, the essentialist member of the pair was evaluated as higher in essentialism than the other member of the pair, and the anti-essentialist member as higher in anti-essentialism than the other member. This testifies to the effectiveness of the manipulation. More importantly, however, there was much more agreement among the residents of both cities on the conservative features of the essentialist city than on the progressive features of the anti-essentialist city. To give an example, residents of both Torun and Bydgoszcz agreed that Torun is an essentialist place, but only residents of Bydgoszcz perceived Bydgoszcz as an anti-essentialist place. The overall 
higher agreement on the essentialist than anti-essentialist features of real places is an argument that evaluations of places as zessentialists are anchored in objective features of places to a higher extent than evaluations of places as anti-essentialists. Thus, the essentialist meaning is retrieved, while the anti-essentialist one is constructed.

In the same study, the participants (except for Torun-Bydgoszcz) evaluated their attachment to their city of residence. In five out of six cities, the score in the rated essentialism of a city was a better predictor of place attachment than the score in the place anti-essentialism, which confirms our previous findings. This was particularly visible in Warsaw, which is by far the most anti-essentialist place in our study. To summarize, much to our surprise, even when realistic stimuli were involved, essentialist features showed psychological priority over anti-essentialist ones.

\section{COMEBACK OF ESSENTIALISM: ENVIRONMENTAL AESTHETICS AND THE NATURE OF ORDER}

Essentialism, whether in its ontological or psychological form, returned to environmental research through theories of environmental aesthetics. Aesthetics is a branch of philosophy that deals with people's judgments of beauty. Environmental aesthetics is a subdiscipline of aesthetics that investigates people's preferences with regard to the natural and built environment. Environmental aesthetics seeks to answer the question of why people consider some places beautiful and aesthetically pleasing, while others are repulsive or uninteresting. Defined as such, environmental aesthetics has a lot to do with the issues discussed here - that is, with the question of what transforms physical settings into positively evaluated meaningful places. Not surprisingly then, the issue of whether beauty is a property of the perceived real objects, that is, whether there exist realistic, "essentialist", criteria of beauty or whether beauty is "in the eye of the beholder" and thus subjective and constructed, has been the leitmotif of numerous theories of aesthetics. This is not the place for presentation of the multitude of different aesthetic theories (Levinson, 2003). Most psychologists, including environmental psychologists, would probably vote for an approach that assumes that aesthetic judgments are products of an interaction of properties of objects and properties of human perceptual and processing capacities. For example the popular perceptual fluency theory (Reber et al., 2004) assumes that people prefer stimuli that ensure fluent processing, that is, those that can be easily recognized and incorporated into existent structures of knowledge. This is why preferred stimuli are prototypical (e.g., typical faces), symmetrical, familiar, and redundant, with good contrast between figure and ground, that is, stimuli that 
are "good gestalts". This theory, as many others, assumes that since people's brains have the same structures, universal laws of aesthetic preferences exist that have their roots in the physiology of the human brain (Francuz, 2013).

Human brains have evolved as instruments that allow for coping with environmental challenges, protecting an organism against premature death, and enabling it to learn new skills. According to popular evolutionary theories of environmental aesthetics, what we like and what we dislike in our environments are "physiological memories" of our evolutionary past. In other words, we learned to like environments that are pragmatically useful, protective on the one hand, and offering opportunities for development on the other hand. One such theory is Jay Appleton's prospect-refuge theory (Appleton, 1984); the refuge offers security, and the prospect offers opportunities for exploration. The other is the theory formulated by Rachel and Steven Kaplans (1989), which posits that environmental preferences serve to satisfy two basic motives: preservation of the status quo and development of new skills. The first motive is satisfied by such environmental features as coherence and legibility, and the other by complexity and mystery. Since the evolutionary past is shared by all humans, these preferences are assumed to be universal and culture-independent.

The processing fluency hypothesis and the evolutionary theories of environmental aesthetics do not contradict each other. The security motives (preservation of the status quo, refuge) are best satisfied by environments that are familiar, easy to understand, legible, well structured, and not requiring too complex information processing. The developmental motive, in turn, is the best satisfied in environments that offer challenge, encourage exploration (prospect, mystery, novelty) and intellectual effort (are sufficiently complex) (see also Cooper \& Silvia, 2009 for the discussion of the relationship between aesthetic appreciation and action). Moreover, since the security motive has precedence over the developmental one (Maslow, 1943), human preferences tend to lean toward fluency, refuge, legibility, and coherence rather than complexity, prospect, novelty, and mystery. Hence, there is also a general appreciation of settings that conform to essentialist criteria, since they are a better guarantee of security than are dynamically changing and physically complex anti-essentialist settings.

Evolutionary approaches to human aesthetic preferences have recently obtained strong support from the biophilic movement. Discussions on how to prevent climate change, and the awareness of the destructions that humans have brought to the natural environment induced architects and urban planners to turn their attention to the role of nature - the source of health and salvation to the planet. Biophilia is a natural, evolutionarily determined human tendency to be attracted to nature (Wilson, 1984). Numerous studies demonstrate that natural scenes are preferred to built environments, and that the human brain reacts differently to the two types of settings 
(Norwooda et al., 2019). However, within the area of environmental aesthetics, the biophilic approach means more than a focus on nature as a source of pleasant experiences. According to certain theories (Alexander, 2001; Joye, 2007; Salingaros, 2012; Taylor, 2006), the human biophilic bias is also generalized onto the built environment, given that the human-made constructions share certain properties with natural stimuli, for example, the presence of fractal patterns. Nature has a fractal structure, which means that its different elements, such as leaves and tree branches, are composed of self-similar patterns that recur on progressively smaller scales, creating minute replicas of the whole structure. As a result, natural stimuli are easy to process, despite their spurious complexity (Joye et al., 2016). Being complex and simple, they can both attract and restore the exhausted attention. People's brains are therefore tuned to appreciate fractals, since this is the human evolutionary heritage. No wonder then that the traditional architecture made ample use of ornaments and decorations that are rich in fractal patterns (Abdullahi \& Embi, 2015; Homolacs, 1930; Saglam, 2014). Fractal ornaments decorate wooden doors, church columns, porticos, and vaults of buildings in different cultures and countries, which are major attractions among tourists visiting historical cities.

In the 20th century, the traditional architecture that drew extensively from natural motives was replaced by the modernist movement, which stood in stark opposition to it. Stripped of ornamentation and symbolism, modernism opts instead for simple forms that are fully instrumental with respect to their function. Modernism also explicitly ignores history. "Less is more," as the famous saying of Mies van der Rohe goes. Reinforced by modern technology, modernist architecture dominated post-war cities on several continents. However, the simple and elegant forms of modernism appear to go against human natural tastes, which lean toward architecture that is historical and rich in detail (Mouratidis \& Hassan, 2020). This was commented on by mathematician Salingaros, a severe critic of modernism: "Ornament is a valuable component in any architecture of buildings and cities that aims to connect to human beings. The suppression of ornament, however, results in alien forms that generate physiological and psychological distress" (Salingaros, 2006, p. 16), and in another place, "Fractal structure distinguishes between human and inhuman cities" (Salingaros, 2005, pp. 11-12). These claims were corroborated by studies using eye-tracking methods, identifying the spontaneous and largely unconscious patterns of attention paid to stimuli with and without ornaments (Salingaros \& Sussman, 2020).

Criticism of modern architecture has been voiced by numerous architects. What these voices have in common is the assumption that human beings have an innate ability to intuitively appreciate beauty as emanating from the natural organization of things and that modernism violates this natural organization. One of the most well-known critics of modernism is Christopher Alexander, an author of the mon- 
umental A Pattern Language (Alexander et al., 1977), and of an even more monumental four-volume, The Nature of Order (Alexander, 2001). Pattern language is a theory of building that assumes that, in analogy to the natural language that people use despite not being aware of its syntax and grammatical rules, there exists a language of implicit aesthetic judgments that is shared by the majority of people and that is largely culture-independent. A pattern is a basic unit of this language. The book A Pattern Language describes 253 patterns that all aim to solve some important design problems by offering a universally accepted solution. Patterns are recipes on how to design good places: global patterns define a town and a community, more specific patterns describe shapes of buildings and spaces between buildings, and the most detailed patterns help design the buildings' interiors. Patterns are "bricks" that can be combined into larger chains much similar to words making up sentences, thus forming complex and living city structures.

Since patterns are assumed to describe universally meaningful places, in one of our studies, we investigated whether they would describe places with essentialist or anti-essentialist features (Iwańczak \& Lewicka, 2020). To this end, we asked participants, residents of Warsaw, to evaluate a series of pictures covering different settings in the city with respect to the raised affect (relaxation, excitement, irritation, boredom). Competent judges also evaluated the settings with respect to the presence of a selected sample of patterns. The results showed that the higher the number of patterns identified in a setting, the more the place was liked and evaluated as more aesthetically pleasing. Moreover, the presence of patterns was mainly predictive of the emotion of relaxation rather than excitement, which is an indirect argument that the pattern language describes essentialist rather than anti-essentialist features of the built environment.

Alexander's essentialist thinking is even more present in his four-volume opus The Nature of Order (Alexander, 2001) and in the last book with the telling title The Battle for the Life and Beauty of the Earth (Alexander et al., 2012). Here, the crucial concept is "life", as the essential property of any meaningful place. In his own words:

What we call "life" is a general condition which exists, to some degree or other, in every part of space: brick, stone, grass, river, painting, building, daffodil, human being, forest, city. And further. The key to this idea is that every part of space- every connected region of space, small, or large - has some degree of life, and that this degree of life is well defined, objectively existing, and measurable. (Alexander, 2001, p. 77)

Not all things have life. Which of the two doors has more life, one with a rough surface and an interior pattern consisting of several levels of scale, or the other with a smooth surface and a pattern with one scale only? People have no trouble 
answering this question, pointing to the first door. According to the theory of natural order, things that have life, whether natural or built by humans, display features that conform to 15 principles, one of which is the fractal nature (levels of scale). Other features concern the organization of the field (strong centers, contrast, local symmetries, boundaries, good shape, alternating repetitions), while others describe the surface qualities (roughness, gradients, echoes, or "inner calm") (Alexander, 2001). Most probably, the principles are not independent of each other, and a factor analysis may yield few independent factors or, perhaps, some of the features may turn out more central than others. Nevertheless, they all describe conditions that determine whether a place is perceived either as an "organic whole" endowed with life or as a set of disconnected, lifeless elements, so typical of modern architecture.

Alexander's attempt at quantification of the principles of organic order met with warm reception in various circles: it attracted the interest of people dealing with art and with science alike. Two specific principles of order, levels of scale and contrast, and their relationship with the perception of "life" in architecture were subject to empirical scrutiny in a study by Coburn et al. (2019). Participants evaluated a series of pictures of architecture, differentiated with respect to the levels of scale and contrast, with respect to how natural they looked and how liked they were. Architecture with higher levels of scale and higher contrast was perceived as more natural (having "life") and was liked more than architecture with lower scores on these dimensions. As predicted, historical architecture scored higher on levels of scale and contrast and was perceived as more natural than modern architecture. The authors concluded that naturalistic visual patterns may play an important role in aesthetic evaluations of architectural scenes. There is no doubt that, given the biophilic shift in the contemporary world, this idea will be further explored. Essentialism in environmental aesthetics has got a new life.

\section{CONCLUDING REMARKS}

Silvan Tomkins, a psychologist and philosopher, is the author of the theory of ideological polarization that divides people's views into left-wing (humanistic) and right-wing (normative) ideologies (Tomkins, 1963). The major difference between the two worldviews lies in whether a human being is considered a measure of all things, assigned an autonomous value, or whether individuals, their behaviors and cognitions, have a status of instruments in the hands of independent, objective forces. The first stand is anti-essentialist, the other, essentialist. The left-right distinction permeates all life domains: morality, religion, economy, children's upbringing, 
education, science, and art. It is a matter of empirical studies to show whether human essentialist environmental preferences coincide with essentialist beliefs in other domains. Some findings suggest that various personality dimensions associated with essentialist vs. anti-essentialist thinking, such as openness to experience and sensation seeking, and political attitudes, conservative vs. liberal, correlate with preferences for different types of art: traditional, representational vs. abstract or critical (Feist \& Brady, 2004; Furnham \& Bunyan, 1988; Mowen et al., 2010; Szubielska \& Imbir, 2021). However, as suggested by Tomkins (1963), the right-left distinction permeates so many areas of life that it would be unrealistic to imagine the intercorrelations between all of them.

Essentialism in environmental aesthetics, as represented by Alexander and researchers with similar views, can be (and actually is) deeply humane and therefore has little to do with the conservative, normative views usually associated with essentialism. It is people who matter, and their tastes should be taken into account when designing our cities and buildings. A plethora of findings demonstrate that these tastes follow the principles of the biophilic patterns. Such is therefore the source of the classic "conservative" theories of place, which —as I have tried to show-find more empirical support than the "progressive" theories. Our evolution has made us appreciate environments that, even if artificially created, are built in analogy with other living structures. In consequence, our tastes in the area of both natural and built environments are not freely constructed. Irrespective of whether this provides a rationale for ontological essentialism or whether it is an explanation of psychological essentialism, such essentialist environments make us feel at ease, in harmony with ourselves and the nature around us.

\section{REFERENCES}

Abdullahi, Y., \& Embi, M. R. (2015). Evolution of abstract vegetal ornaments in Islamic architecture. International Journal of Architectural Research, 9(1), 31-49.

Agnew, J. (1987). Place and politics: The geographical mediation of state and society. Allen \& Unwin. Alexander, C. (2001). The nature of order. An essay on the art of building and the nature of the universe. Book 1: The phenomenon of life. The Center for Environmental Structure.

Alexander, C., Neis, H. J., \& Alexander, M. M. (2012). Battle for the life and beauty of the earth. A struggle between two world systems. Oxford University Press.

Alexander, C., Silverstein, M., Angel, S., Ishikawa, S., \& Abrams, D. (1975). The Oregon experiment. Oxford University Press.

Alexander, C., Silverstein, M., Angel, S., Ishikawa, S., \& Abrams, D. (1977). A pattern language. Oxford University Press. 
Andreychik, M. R., \& Gill, M. J. (2015). Do natural kind beliefs about social groups contribute to prejudice? Distinguishing bio-somatic essentialism from bio-behavioral essentialism, and both of these from entitativity. Group Processes \& Intergroup Relations, 18(4), 454-474. https://doi.org/10.1177/1368430214550341

Appleton, J. (1984). Prospects and refuges revisited. Landscape Journal, 3, 91-104. https://doi.org/10.3368/lj.3.2.91

Augé, M. (1995). Non-places. An introduction to supermodernity. Verso.

Bachelard, G. (1994). The poetics of space. Beacon Press.

Brodwin, P. (2002). Genetics, Identity, and the Anthropology of Essentialism. Anthropological Quarterly, 75(2), 323-330. Retrieved May 7, 2021, from http://www.jstor.org/stable/3318263

Chen, J. M., \& Ratliff, K. A. (2018). Psychological essentialism predicts intergroup bias. Social Cognition, 36(3), 301-323. https://doi.org/10.1521/soco.2018.36.3.301

Cimpian, A., \& Salomon, E. (2014). The inherence heuristic: An intuitive means of making sense of the world, and a potential precursor to psychological essentialism. Behavioral and Brain Sciences, 37(5), 461-480. https://doi.org/10.1017/S0140525X13002197

Coburn, A., Kardan, O., Kotabe, H., Steinberg, J., Hout, M. C., Robbins, A., MacDonald, J., Hayn-Leichsenring, G., \& Berman, M. G. (2019). Psychological responses to natural patterns in architecture. Journal of Environmental Psychology, 62, 133-145. https://doi.org/10.1016/j.jenvp.2019.02.007

Cooper, J. M., \& Silvia, P. J. (2009). Opposing art: Rejection as an action tendency of hostile aesthetic emotions. Empirical Studies of the Arts, 27(1), 109-126. https://doi.org/10.2190/EM.27.1.f

Cresswell, T. (2004/2015). Place: A short introduction. Blackwell Publishing.

Cresswell, T. (2006). On the move. Mobility in the modern western world. Routledge.

Demoulin, S., Leyens, J.-P., \& Yzerbyt, V. (2006). Lay theories of essentialism. Group Processes and Intergroup Relations, 9, 25-42. https://doi.org/10.1177/1368430206059856

Di Masso, A., Williams, D. R., Raymond, C., Buchecker, M., Degenhardt, B., Devine-Wright, P., Hertzog, A., Lewicka, M., Manzo, L. C., Shahrad, A., Stedman, R., Verbrugge, L., \& von Wirth, T., (2019). Between fixities and flows: Navigating place attachments in an increasingly mobile world. Journal of Environmental Psychology, 61, 125-133. https://doi.org/10.1016/j.jenvp.2019.01.006

Dovey, K. (2010). Becoming places. Urbanism/Architecture/Identity/Power. Routledge, Taylor \& Francis Group.

Feist, G. J., \& Brady, T. R. (2004). Openness to experience, non-conformity, and the preference for abstract art. Empirical Studies of the Arts, 22(1), 77-89. https://doi.org/10.2190/Y7CA-TBY6V7LR-76GK

Fornara, F., Ariccio, S., Rioux, L., Moffat, E., Mariette, J., \& Bonnes, M. (2018). Vérification de la structure factorielle et de la fiabilité des preqis en France et test d'un modèle de prédiction de l'attachement au quartier: une étude sur un échantillon parisien [Test of PREQIs' factorial structure and reliability in France and of a neighbourhood attachment prediction model: A study on a French sample in Paris]. Pratiques Psychologiques, 24, 131-156. https:// doi.org/10.1016/j.prps.2017.07.004

Francuz, P. (2013). Imagia. W strone neurokognitywnej teorii obrazu. Wydawnictwo KUL.

Fried, M. (2000). Continuities and discontinuities of place. Journal of Environmental Psychology, 20, 193-205. https://doi.org/10.1006/jevp.1999.0154

Furnham, A. , \& Bunyan, M. (1988). Personality and art preferences. European Journal of Personality, 2, 67-74. https://doi.org/10.1002/per.2410020106

Gelman, S. A. (2003). The essential child: Origins of essentialism in everyday thought. Oxford University Press. 
Gelman, S. A. (2013). Artifacts and essentialism. Revue of Philosophical Psychology, 4(3), 449-463. https://doi.org/10.1007/s13164-013-0142-7

Gembarski, M., \& Dzieciątkowski, S. (2020). Teoria miejsca w kontekście cyfrowego świata gier komputerowych [Theory of place in the context of the digital world of computer games]. Unpublished research paper. Nicolaus Copernicus University in Torun.

Gieryn, T. F. (2000). A space for place in sociology. Annual Review of Sociology, 26, 463-496. https:// www.jstor.org/stable/223453

Gil-White, F. J. (2001). Are ethnic groups biological "species" to the human brain? Essentialism in our cognition of some social categories. Current Anthropology, 42(4), 515-554. https:// doi.org/10.1086/321802

Gilbert, D. T., \& Malone, P. S. (1995). The correspondence bias. Psychological Bulletin, 117(2), 21-38. https://doi.org/10.1037/0033-2909.117.1.21

Harvey, D. (1993). From space to place and back again: Reflections on the conditions of postmodernity. In J. Bird, B. Curtis, T. Putnam, G. Robertson, \& L. Tickner (Eds.), Mapping the futures: Local cultures, global change (pp. 3-29). Routledge.

Hamilton, D. L., \& Sherman, S. J. (1996). Perceiving persons and groups. Psychological Review, 103, 336-355. https://doi.org/10.1037/0033-295X.103.2.336

Haslam, N., Rothschild, L., \& Ernst, D.(2000). Essentialist beliefs about social categories. British Journal of Social Psychology, 39, 113-127. https://doi.org/10.1348/014466600164363

Haslam, N., Rothschild, L., \& Ernst, D. (2002). Are essentialist beliefs associated with prejudice? British Journal of Social Psychology, 41, 87-100. https://doi.org/10.1348/014466602165072

Heidegger, M. (1962). Being and Time (J. Macquarrie and E. Robinson, Trans.). SCM Press.

Heidegger, M. (1970). Budować, mieszkać, myśleć. Eseje wybrane [Build, dwell, think. Selected essays] (K. Michalski, Trans.). Czytelnik.

Homolacs, K. (1930). Budowa ornamentu i harmonia barw. Dydaktyka zdobnictwa [Structure of ornament and the harmony of colors. Teaching decoration]. Miejskie Muzeum Przemysłowe im. dra A. Baranieckiego.

Iwańczak, B., \& Lewicka, M. (2020). Affective map of Warsaw. Testing Alexander's Pattern Language theory in an urban landscape. Landscape and Urban Planning, 204, 103910. https://doi.org/10.1016/j.landurbplan.2020.103910

Jarczyk, P. (2020). Waloryzacja miejsc przyrodniczych konserwatywnych i progresywnych z uwzględnieniem teorii estetyki środowiskowej Rachel i Stephena Kaplanów [Valuation of natural conservative and progressive places with reference to the theory of aesthetics by Rachel and Stephen Kaplan]. Unpublished research paper. Nicolaus Copernicus University in Torun.

Joye, Y. (2007). Architectural lessons from environmental psychology: The case of biophilic architecture. Review of General Psychology, 11(4), 305-328. https://doi.org/10.1037/1089-2680.11.4.305

Joye, Y., Steg, L., Unal, A. B., \& Pals, R. (2016). When complex is easy on the mind: Internal repetition of visual information in complex objects is a source of perceptual fluency. Journal of Experimental Psychology: Human Perception and Performance, 42(1), 103-114. http://doi.org/10.1037/xhp0000105

Kaplan, S., \& Kaplan, R. (1989). The experience of nature. A psychological perspective. Cambridge University Press.

Levinson, J. (Ed.) (2003). The Oxford handbook of aesthetics. Oxford University Press.

Lewicka, M. (2012). Psychologia miejsca [Psychology of place]. Wydawnictwo Naukowe Scholar.

Lewicka, M., Rowiński, K., Iwańczak, B., Bałaj, B., Kula, A. M., Oleksy, T., Prusik, M., Toruńczyk-Ruiz, S., \& Wnuk, A. (2019). On the essentialism of places: Between con- 
servative and progressive meanings. Journal of Environmental Psychology, 65, 101318. https://doi.org/10.1016/j.jenvp.2019.101318

Lewicka, M., \& Urbańska, M. (2021). Miejskie my vs. oni: Symetrie i asymetrie we wzajemnej ocenie miast [Urban us vs. them: Symmetries and asymmetries in mutual perception of cities]. Unpublished research report: Nicolaus Copernicus University in Torun.

Löw, M. (2014). The intrinsic logic of cities: Towards a new theory on urbanism. Urban Research and Practice, 5, 303-315. https://doi.org/10.1080/17535069.2012.727545

Malpas, J. (2008). Heidegger's topology. Being, place, world. MIT Press.

Maslow, A. H. (1943). A theory of human motivation. Psychological Review, 50(4), 370-396. https://doi.org/10.1037/h0054346

Massey, D. (1993). Power-geometry and a progressive sense of place. In J. Bird, B. Curtis, T. Putnam, G. Robertson, \& L. Tickner, (Eds.), Mapping the futures: Local cultures, global change (pp. 59-69). Routledge.

Mayr, E. (1968). Theory of biological classification. Nature, 220, 545-548. https:// doi.org/10.1038/220545a0

Medin, D. L. (1989). Concepts and conceptual structures. American Psychologist, 44, 1469-1481. https://psycnet.apa.org/doi/10.1037/0003-066X.44.12.1469

Medin, D. L., \& Ortony, A. (1989). Psychological essentialism. In S. Vosniadou \& A. Ortony (Eds.), Similarity and analogical reasoning (pp. 179-195). Cambridge University Press.

Medin, D. L., \& Rips, L. J. (2002). Concepts and categories: Memory, meaning, and metaphysics. In K. J. Holyoak \& R. G. Morrison (Eds.), The Cambridge handbook of thinking and reasoning (pp. 37-72). Cambridge University Press.

Merlaeu-Ponty, M. (1945). Phénoménologie de la perception. Gallimard.

Norwooda, M. F., Lakhania, A., Maujeanb, A., Zeemana, H., Creuxa, O., \& Kendalla, E. (2019). Brain activity, underlying mood and the environment: A systematic review. Journal of Environmental Psychology, 65, 101321. https://doi.org/10.1016/j.jenvp.2019.101321

Mouratidis, K., \& Hassan, R. (2020). Contemporary versus traditional styles in architecture and public space: A virtual reality study with 360-degree videos. Cities, 97, 102499. https:// doi.org/10.1016/j.cities.2019.102499

Mowen, J. C., Fang, X., \& Scott, K. (2010). Visual product aesthetics: A hierarchical analysis of its trait and value antecedents and its behavioral consequences. European Journal of Marketing, 44(11/12), 1744-1762. https://doi.org/10.1108/03090561011079864

Norberg-Schulz, C. (1980). Genius loci, Towards a phenomenology of architecture. Rizzoli International Publications.

Porteous, J. D. (1976). Home: The territorial core. Geographical Review, 66, 383-390. https:// doi.org/10.2307/213649

Reber, R., Schwarz, N., \& Winkielman, P. (2004). Processing fluency and aesthetic pleasure: Is beauty in the perceiver's processing experience? Personality and Social Psychology Review, 8, 364-382. https://doi.org/10.1207\%2Fs15327957pspr0804_3

Relph, E. (1976). Place and placelessness. Pion Limited.

Rhodes, M., Leslie, S.-J., \& Tworek, C. M. (2012). Cultural transmission of social essentialism. PNAS, 109(34), 13526-13531. https://doi.org/10.1073/pnas.1208951109

Rhodes, M., \& Mandalaywala, T. M. (2017). The development and developmental consequences of social essentialism. WIREs Cognitive Science, 8 :e1437. https://doi.org/10.1002/wcs.1437

Røe, P. G. (2014). Analysing Place and Place-making: Urbanization in Suburban Oslo. International Journal of Urban and Regional Research, 38(2), 498-515. https://doi.org/10.1111/14682427.12113 
Ross, L. (1977). The Intuitive Psychologist And His Shortcomings: Distortions in the Attribution Process. Advances in experimental social psychology, 10, 173-220. https://doi.org/10.1016/S0065-2601(08)60357-3

Russell, J. A. (1980). A circumplex model of affect. Journal of Personality and Social Psychology, 39, 1161-1178. https://doi.org/10.1037/h0077714

Saglam, H. (2014). Re-thinking the concept of "ornament" in architectural design. Procedia - Social and Behavioral Sciences, 122, 126-133. https://doi.org/10.1016/j.sbspro.2014.01.1314

Salingaros, N. A. (2005). Principles of urban structure. Techne Press.

Salingaros, N. A. (2006). A theory of architecture. Nikos Salingaros \& Umbau-Verlag.

Salingaros, N. A., \& Sussman, A. (2020). Biometric pilot-studies reveal the arrangement and shape of windows on a traditional façade to be implicitly "engaging", whereas contemporary façades are not. Urban Science, 4, 26. https://doi.org/10.3390/urbansci4020026

Salingaros, N. A. (2012). Fractal art and architecture reduce physiological stress. Journal of Biourbanism, 2, 11-28.

Seamon, D. (1980). Body-subject, time-space routines, and place-ballets. In A. Buttimer \& D. Seamon (Eds.), The human experience of space and place (pp. 148-165). St. Martin's Press.

Sober, E. (1980). Evolution, population thinking, and essentialism. Philosophy of Science, 47, 350-383. http://www.jstor.org/stable/186950

Steele, F. (1972). The sense of place. CBI Publishing Company.

Szubielska, M., \& Imbir, K. (2021). The aesthetic experience of critical art: The effects of the context of an art gallery and the way of providing curatorial information. PLoS ONE 16(5): e0250924. https://doi.org/10.1371/journal.pone.0250924

Taylor, R. P. (2006). Reduction of physiological stress using fractal art and architecture. Leonardo. Retrieved May 9, 2021, from http://www.mitpressjournals.org/doi/pdfplus/10.1162/ leon.2006.39.3.245

Tomkins, S. (1963). The right and the left: A basic dimension of ideology and personality. In R. W. White (Ed.), The study of lives (pp. 389-411). Atherton Press.

Tuan, Y. F. (1977). Space and place: The perspective of experience. University of Minnesota Press.

Wilson, E. O. (1984). Biophilia. Harvard University Press.

Wu, N., \& Silva, E. A. (2011). Urban DNA: Exploring the biological metaphor of urban evolution with DG-ABC model. Retrieved from https://agile-online.org/conference_paper/cds/agile_2011/ contents/pdf/shortpapers/sp_149.pdf

Yzerbyt, V., Rocher, S., \& Schadron, G. (1997). Stereotypes as explanations: A subjective essentialistic view of group perception. In R. Spears, P. J. Oakes, N. Ellemers, \& S. A. Haslam (Eds.), The social psychology of stereotyping and group life (pp. 20-50). Blackwell Publishers. 